\title{
BIOGRAFI PENGUSAHA HOTEL SEBAGAI SUMBER SEJARAH PARIWISATA BALI
}

\author{
Slamat Trisila \\ Magister Kajian Budaya Program Pascasarjana \\ Universitas Udayana \\ Email: puing@mail.com
}

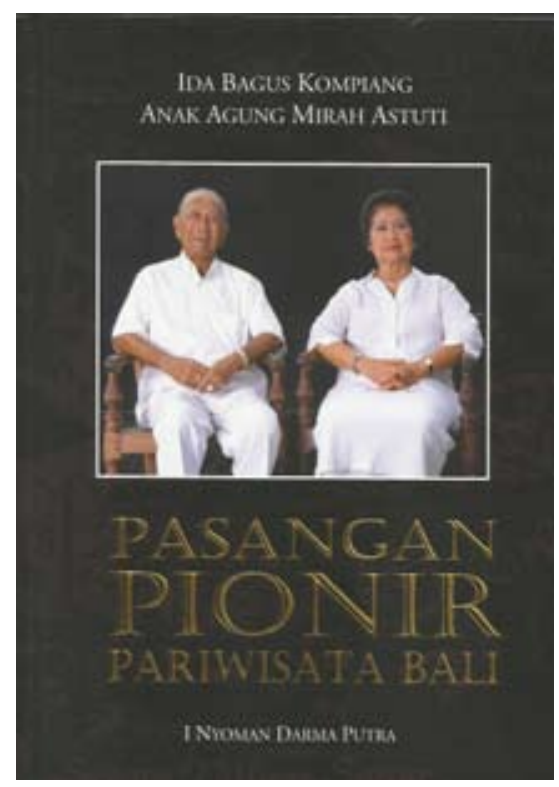

Judul buku : Pasangan Pionir Pariwisata Bali; Ida Bagus Kompiang, Anak Agung Mirah Astuti

Penulis : I Nyoman Darma Putra Penerbit : Jagat Press, Denpasar Tahun

Tebal : 2012 : $411 \mathrm{hlm}$

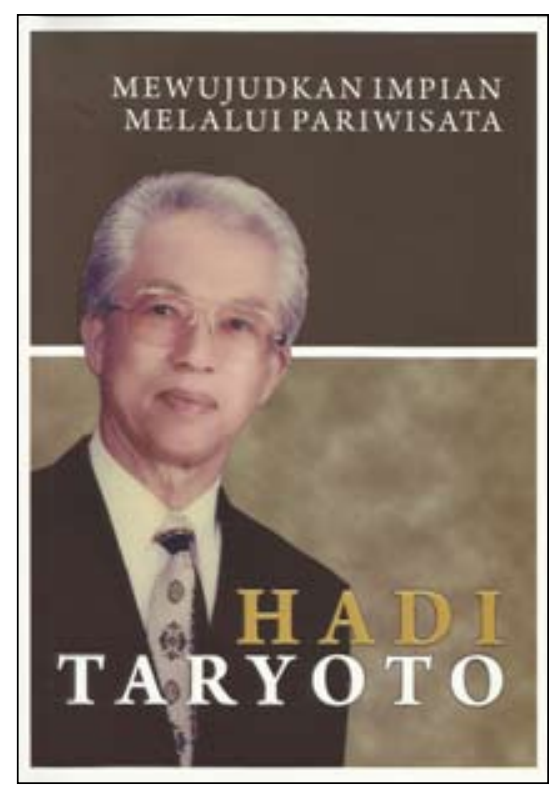

Judul buku :Mewujudkan Impian melalui Pariwisata; Hadi Taryoto

Penulis : : I Nyoman Darma Putra Penerbit : Pustaka Larasan Tahun : 2014

Tebal : i-xix; 246 hlm

\section{Pengantar}

alam dua tahun terakhir ini, terbit dua biografi pengusaha
hotel di Bali. Kedua buku ini ditulis oleh I Nyoman Darma Putra, yang sebelumnya sudah menerbitkan beberapa buku kebudayaan dan pariwisata termasuk Tourism Development and Terrorism in Bali (2007, ditulis bersama Michael Hitchcock) dan Pariwisata Pro-Rakyat; Meretas Jalan Mengentaskan Kemiskinan 
di Indonesia (2010; bersama I Gde Pitana). Walaupun kedua buku biografi ini merupakan kisah pribadi tokoh-tokohnya, buku-buku ini kaya akan informasi yang berguna untuk menyusun sejarah pariwisata Bali.

Pariwisata Bali sudah berkembang seabad lebih, paling tidak sejak 1910-an ketika pemerintah kolonial Belanda mulai mempromosikan Bali sebagai daerah tujuan wisata. Langkah Belanda itu dilanjutkan dengan mendorong maskapai pelayaran KPM Belanda untuk mulai mengangkut turis ke Bali sejak 1920an, dilanjutkan dengan membuka hotel pertama di Denpasar, yakni Bali Hotel, tahun 1928. Walaupun sudah berusia hampir seratus tahun, sejarah pariwisata Bali yang komprehensif sama sekali belum ditulis.

Memang ada banyak studi tentang pariwisata Bali seperti karya Adrian Vickers (2011 [1989]) dan Michel Picard (1996) yang secara khusus membahas aspek pencitraan Bali sebagai paradise (surga) dan dampak pariwisata terhadap kebudayaan Bali; tulisan sejarah secara khusus yang mengangkat peran tokoh-tokoh lokal belum ada sama sekali. Kajian terhadap pariwisata Bali juga sering menjadi bagian studi dari bidang ilmu lain, seperti lingkungan, antropologi, dan ekonomi, tetapi sejarah khusus pariwisata Bali belum pernah ditulis.

Menulis sejarah pariwisata Bali tidaklah mudah, seperti diakui I Nyoman Darma Putra, karena jangkauannya luas dan aspek yang perlu diperhatikan banyak sekali. Sementara itu, bahan-bahan untuk itu semakin sulit diperoleh karena banyak bahan yang lenyap bersama perjalanan waktu.

Dalam buku biografi Hadi taryoto, Darma Putra menegaskan mengenai kesulitan menulis sejarah pariwisata sebagai berikut:

Hambatan menulis sejarah pariwisata Bali makin lama makin menghadapi beberapa hambatan. Pertama, karena arsip semakin sulit diperoleh. Kedua, tokoh-tokoh yang menjadi pelaku pariwisata semakin lama semakin berkurang atau kehilangan 
memori karena faktor usia. Terlepas dari kesulitan itu, tinggal diam tanpa menulis apa pun mengenai aspek-aspek historis pariwisata Bali tentu saja keliru (2014:3).

Tepat sekali, bahwa berpangku tangan alais tidak melakukan apa-apa akan membuat berbagai informasi akan semakin sulit didapat.

Ungkapan Darma Putra dia wujudkan sendiri dengan menulis biografi tokh-tokoh pariwisata. Para tokoh yang ditulis mengungkapkan pengetahuan, pengalaman, dan kiprahnya dalam dunia pariwisata Bali sehingga apa yang disampaikan itu sebetulnya merupakan untaian sejarah pariwisata Bali pula.

\section{Pionir Pariwisata Bali}

Buku Pasangan Pionir Pariwisata Bali ditulis dalam 25 bab, mengisahkan masa kecil dua tokohnya, yang merupakan pasangan suami istri. Tokoh suami, Ida Bagus Kompiang dilukiskan sejak masa kecil hingga dewasa sampai berusia 86 tahun, saat buku rampung ditulis. Dalam rentang waktu itu, dilukiskan masa sekolahnya, masa mulai terjun ke dunia bisnis, dan akhirnya membangun hotel pertama di Sanur tahun 1956/57. Tokoh istri, Anak Agung Mirah Astuti, dilukiskan saat-saat dia mulai berpacaran dengan Ida Bagus Kompiang, sampai dengan kolaborasi mereka berdua membangun hotel, mengelola art shop, melakukan ekspor kerajinan, dan sebagainya.

Buku ini menegaskan bahwa Ida Bagus Kompiang dan Mirah Astuti adalah pasangan pionir yang tampil sebagai orang lokal/Bali pertama yang membangun hotel di Sanur. Mereka mendirikan Segala Beach Hotel yang kini dikenal menjadi Segara Village Hotel. Hotel ini didirikan tahun 1956, alias sepuluh tahun lebih awal dari pendirian/pengoperasian Hotel Bali Beach.

Dalam risetnya, Darma Putra menyebutkan bahwa Hotel Bali Beach membeli lokasi Hotel Segara Beach. Dari hasil penjualan itu, Ida Bagus Kompiang membeli tanah di seberang selatan, yang kini menjadi lokasi Segara Village Hotel. Ida Bagus Kompiang 
menjual hotle itu kepada pemerintah demi kemajuan pariwisata, sementara dia sendiri melanjutkan usahanya di sebelah selatan.

Pada saat pembangunan Hotel Bali Beach, Ida Bagus Kompiang menjadi Direktur Utama PT Hotel Bali Beach, sementara hotelnya sendiri dikelola oleh istrinya, AA Mirah Astuti. Dengan demikian, Mirah Astuti bukan istri biasa yang hanya mengurus masalah domestik, tetapi juga seorang wanita Bali yang tanggung dalam usaha jasa akomodasi. Mereka berfikiran maju membangun hotel jauh sebelum orang lain melirik bisnis ini, tetapi juga berhasil membangun dan melanjutkan usaha itu sampai sekarang, sampai mewariskannya kepada cucu-cucunya, lintas generasi.

Di akhir hayatnya, Ida Bagus Kompiang yang pernah menjadi Ketua PHRI Bali, Ketua Legiun Veteran RI, dan menjadi Konsul Kehormatan beberapa negara Skandinavia termasuk Swedia, Denmark, Norwegia, dan Skotlandia. Jabatan itu diteruskan kepada anaknya Ida Bagus Ngurah Wijaya dan juga kepada cucunya Ida Bagus Kharisma Wijaya (lihat “Konsul LIntas Generasi", hlm 191-210). Peran sebagai konsul kehormatan saling mendukung dengan usahanya dalam bisnis pariwisata.

Mamasuki masa pensiun, pasangan pionir pariwisata ini memutuskan untuk menjadi pendeta, mengabdi pada agama, menekuni dunia spiritualitas. Kepeloporannya di bidang pariwisata berlanjut, diteruskan oleh anak dan cucunya.

\section{Dari Pekerja sampai Pengusaha}

Buku Mewujudkan Impian melalui Pariwisata ditunagkan dalam 32 Bab, melukiskan perjalanan hidup Hadi Taryoto mulai dari masa kecil, sekolah, dan kuliah perhotelan sampai akhirnya menjadi pemilik dua hotel berbintang di Kuta. Di bab-bab terkahir terdapat tetimoni dari beberapa sahabat karib Hadi Taryoto, yang diajak berjuang dalam pengembangan pariwisata Bali.

Hadi Taryoto berasal dari Cirebon, dan begitu taman dari Akademi Perhotelan Nasional Bandung tahun 1966 langsung mendapat pekerjaan di Hotel Bali Beach Sanur, hotel yang ikut dibangun oleh Ida Bagus Kompiang (biografi pertama). Satu 
angkatan teman kuliah Hadi Taryoto, berjumlah sekitar 40 orang, semuanya mendapat pekerjaan di Bali Beach Hotel. Di Bali sendiri jumlah SDM yang siap bekerja di Bali Beach masih kurang sehingga didatangkan dari Bandung.

Setelah beberapa tahun bekerja di Bali Beach, Hadi taryoto yang cerdas dan terampil mendapat kepercayaan untuk job training ke Bangkok, tepatnya The Siam Hotel Intercontinental. Saat itu, Hotel Bali Beach dikelola manajemrn Intercontinental, sehingga pertukaran pekerja, merupakan hal yang biasa dan bagi karyawan hal itu menguntungkan untuk mencari pengalaman internasional.

Setelah job training di Bangkok, Hadi Taryoto mendapat kesempatan mengikuti pendidikan hospitality di Cornell, Amerika Serikat. Sepulang dari sana, di mendapat promosi di Bali Beach dan kemudian mendapat tawaran untuk menjadi Assistant Executive Manager/Acting Manager di Pertamina Cottages, Tuban. Prestasinya bersinar sehingga dia terus dipercaya menjadi GM di hotel ini sampai 15 tahun.

Hotel Percott yang kemudian menjadi Hotel Patra Jasa mencatat sejarah penting dalam dunia MICE (meeting, incentive, conference, exhibition) di Bali karena di hotel inilah awal-awalnya berlangsung konferensi internasional seperti ASEAN tahun 1976 dan OPEC tahun 1980, jauh sebelum hotel-hotel di Nusa Dua belum berdiri. Sejarah MICE yang kini menjadi salah satu ikon bisnis pariwisata Bali bermula di Percott.

Dalam melakoni profesinya di Percott dan Patra Jasa, Hadi Taryoto bertemu dengan banyak kepala negara, mulai dari president, perdana menteri, sampai dengan raja/ratu termasuk Pangeran Charles. Selain yang hadir untuk meeting, juga yang datang untuk berlibur di Bali. B.J. Habibie dan Ainun Habibie ternyata sering belribur di Percott di akhir tahun, sejak dia menjadi Menristek. Pergaulan akrab antar keluarga Habibie dengan Hadi Taryoto dilukiskan dalam buku ini.

Setelah lama bekerja sebagai professional, Hadi Taryoto pelan-pelan membangun hotelnya sendiri, sampai akhirnya kini 
Hotel Bali rani hadir di Kuta dengan kelas bintang empat. Dia juga memiliki usaha lainnya yang berkaitan dengan dunia hospitality. Sama dengan Ida Bagus Kompiang, Hadi Taryoto pun aktif dalam organisasi profesi kepariwisataan seperti pernah mnejadi Ketua PHRI (sesudah Ida Bagus Kompiang), menjadi Ketua PATA Bali Chapter, membangun Tuban Group, dan aktif dalam kelompok peduli pariwisata Bali Tourism Friends.

Dari sosok Hadi Taryoto, perjalan pariwisata Bali bisa dilihat dengan lebih menarik, misalnya evolusi Kuta Selatan berkembang dari daerah terbelakang menjadi daerah yang maju pariwisatanya dewasa ini.

\section{Banyak Biografi}

Dari dua buku ini, usaha Darma Putra menuliskan kisah biografi tokoh pariwisata patut diapresiasi. Kahdiran buku ini tidak saja menjadi rekaman tersendiri kisah hidup tokoh yang dituturkan, tetapi juga banyak mengandung informasi tonggaktonggak pariwisata Bali. Untuk selanjutnya, langkah Darma Putra menulis biografi ini perlu dilanjutkan oleh sarjana dan penulis lain sehingga lebih banyak lagi buku biografi bisa kita simak. Apalagi memang fakta menunjukkan, Bali memiliki banyak tokoh yang memiliki pengalaman hidup yang menarik dan berjasa dalam perkembangan pariwisata Bali.

Terlepas dari isinya yang berkaitan dengan perjalanan pariwisata Bali, biografi selalulah bisa memberikan inspirasi tertentu pada pembacanya untuk belajar dari atau meniru kesuksesan sang tokoh.

\section{PROFIL PENULIS}

Slamat Trisila adalah mahasiswa S-2 Kajian Budaya Program Pascasarjana Universitas Udayana. Sejak tahun 2001 hingga sekarang mengelola Penerbit Pustaka Larasan. Pengalaman lain, yakni dipercaya sebagai Penyelaras Bahasa pada penerbitan KITLVJakarta, Van Valenhoven Institute-Leiden, dan Yayasan Obor Jakarta. Buku yang telah diterbitkan Denpasar Tempo Doeloe: Melacak Dinamika Kota Denpasar Berbasis Visual (2013). 